\title{
PERANAN PENGURUS KELOMPOK BELAJAR PROGRAM PENDIDIKAN DASAR DALAM PENYELENGGARAAN LAYANAN SISTEM BELAJAR JARAK JAUH DI UPBJJ-UT SERANG
}

\author{
Eha Saleha \\ Universitas Terbuka \\ e-mail: ehasaleha@ecampus.ut.ac.id
}

\begin{abstract}
Group administrators Learning Pendas's students is an important part of the system for implementing distance learning services in each Open University Distance Learning Program Unit. However, the description and research related to the role of the board of education officers is still very limited. To achieve this, descriptive qualitative research has been carried out with participatory action research (PAR) strategies for all PGSD and PGPAUD student management and service activities carried out by pokar administrators throughout the Banten region under the auspices of UPBJJ-UT Serang. The results of the study showed that the administrators of the pendas program had a role in the implementation of distance learning system services at UT Serang UPBJJ especially in promotional activities, new student recruitment, New Student Study Orientation, distribution of teaching materials, PKP / PKM tutorials and compulsory and examination and Diploma Submission Ceremony (UPI).
\end{abstract}

Keywords: Role, Pokjar Management, Distance Education Services

Universitas Terbuka atau yang disingkat dengan UT menerapkan sistem belajar jarak jauh dan terbuka. Istilah jarak jauh berarti pembelajaran tidak dilakukan secara tatap muka, melainkan menggunakan media, baik media cetak (modul) maupun non-cetak (audio/video, komputer/internet, siaran radio, dan televisi). Makna terbuka adalah tidak ada pembatasan usia, tahun ijazah, masa belajar, waktu registrasi, dan frekuensi mengikuti ujian. Batasan yang ada hanyalah bahwa setiap mahasiswa UT harus sudah menamatkan jenjang pendidikan menengah atas (SMA atau yang sederajat) untuk Program Sarjana dan Diploma (Katalog UT Non Pendas, 2015).

Universitas Terbuka mengharapkan mahasiswa UT mampu untuk belajar mandiri. Belajar mandiri dapat dilakukan secara sendiri ataupun berkelompok, baik dalam kelompok belajar maupun dalam kelompok tutorial (Katalog UT Non Pendas, 2015).

Menurut Gede Juliana (2012), kelompok belajar (Pokjar) merupakan inisiatif dari mahasiswa untuk membentuk kelompok diskusi tentang perkuliahan di UT. Kelompok ini tidak termasuk dalam struktur UT, sehingga hal-hal yang dilakukan oleh pokjar adalah diluar tanggung jawab (www.denpasar.ut.ac.id, 2015). Kelompok belajar untuk mahasiswa Fakultas IImu Keguruan dan Pendidikan (FKIP) Program Pendidikan Dasar (Pendas) Program studi Pendidikan Guru Sekolah Dasar (PGSD) S-I dan Pendidikan Guru Anak Usia Dini (PGPAUD) S-I Universitas Terbuka dikelola oleh Unit Program Belajar Jarak Jauh (UPBJJ) bekerjasama dengan Dinas Pendidikan kabupaten/kota masing-masing propinsi hasil kerjasama antara Universitas Terbuka dengan Kementerian Riset, Teknologi dan Pendidikan Tinggi. 
Sebanyak 7.273 mahasiswa Pendas yang telah meregistrasi tersebut mendapatkan layanan belajar jarak jauh yang dikelola oleh pengurus Pokjar. Pengurus Pokjar program Pendas UPBJJ-UT Serang dikelola oleh Dinas Pendidikan se Propinsi Banten dan Unit Pelaksana Teknis TK, SD dan Pendidikan Non Formal dan informal kecamatan dengan penunjukan pegawai atau perwakilan untuk menjadi pengelola kelompok belajar mahasiswa UT yang terdiri dari guru sekolah dasar dan guru pendidikan anak usia dini yang belum menyelesaikan pendidikan sarjana untuk jenjang karir dan jabatannya sesuai dengan peraturan pemerintah No. 74 tahun 2005 tentang guru dan Permendikbud Nomor 62 tahun 2013 tentang Sertifikasi Guru Dalam Jabatan. Untuk melayani calon mahasiswa dan mahasiswa UT yang berada dipelosok desa dan kecamatan di wilayah Banten, pengurus pokjar menjadi mitra dari UPBJJ mulai dari promosi sampai dengan wisuda mahasiswa.

Sejauhmanakah peranan pengurus pokjar terhadap pengelolaan mahasiswa pendas di UPBJJ sampai dengan saat ini belum ditemukan tulisan yang menjawab hubungan kausalitas tersebut dikarenakan belum adanya gambaran jelas tentang apa saja peranan pengurus pokjar selain dibidang promosi Universitas terbuka.

\section{Pengertian Peranan}

Peranan (role) merupakan proses dinamis kedudukan (status). Apabila seseorang melaksanakan hak dan kewajibannya sesuai dengan kedudukannya, dia menjalankan suatu peranan. Perbedaan antara kedudukan dengan peranan adalah untuk kepentingan ilmu pengetahuan. Keduanya tidak dapat dipisah-pisahkan karena yang satu tergantung pada yang lain dan sebaliknya (Soekanto, 2009:212-213). "Peranan tersebut selain ditentukan oleh pelaku peran tersebut juga ditentukan oleh harapan pihak lain, termasuk juga kemampuan, keahlian, serta kepekaan pelaku peran tersebut terhadap tuntutan dan situasi yang mendorong dijalankannya peranan. Peranan juga bersifat dinamis, di mana dia akan menyesuaikan diri terhadap kedudukan yang lebih banyak agar kedudukannya dapat diakui oleh masyarakat” (Soekanto, 2009: 221).

\section{Pengertian Sistem Belajar Jarak Jauh}

Menurut Keegan (1983, dalam Rusyana, 2012:1-2) karakteristik PJJ adalah:

a. Terpisahnya pengajar dan pembelajar yang membedakan pendidikan jarak jauh dengan pendidikan tatap muka.

b. Adanya suatu institusi yang mengelola program pendidikan, inilah yang membedakan dengan kegiatan seseorang yang belajar sendiri di rumah atau studi pribadi.

c. Penggunaan media teknis: cetak, audio, video dan komputer untuk menyatukan pengajar dengan pembelajar dan membawa isi pendidikan.

d. Penyediaan sarana komunikasi dua arah sehingga peserta didik dapat mengambil inisiatif dialog dan mengambil manfaat.

e. Kemungkinan pertemuan sekali-sekali untuk keperluan pengajaran dan sosialisasi.

f. Partisipasi dalam bentuk industrialisasi pendidikan.

\section{Karakteristik Informan}

Profil informan dari pengurus pokjar di UPBJJ-UT Serang diketahui bahwa 4 orang pengurus bekerjasama mulai tahun 1994 dan 19 orang dimulai tahun 2000an, kerjasama tersebut merupakan keberlanjutan dari program kerjasama pada tahun 1990 antara Direktorat Jenderal (Dirjen) Pendidikan Tinggi dengan Dirjen Pendidikan Dasar dan Menengah Kementerian Pendidikan dan Kabudayaan dalam program penyetaraan D2 PGSD. Rata-rata usia pengurus pokjar antara 50-60 
tahun, sebanyak 17 orang atau sebanyak $73,9 \%$ berpendidikan akhir Sarjana (S-I) dan 6 orang atau sebanyak 26,1\% menyelesaikan pendidikan akhirnya dijenjang S2 atau Megister dibidang ilmu keguruan dan pendidikan yang artinya rata-rata pengurus pokjar merupakan lulusan Sarjana (S-I). Dari 23 pengurus, 12 orang atau sebanyak 52,2\% merupakan pengawas SD di UPTD masingmasing pokjar, 7 orang atau sebanyak $30,4 \%$ diantaranya merupakan pegawai negeri yang bekerja di lingkungan dinas Pendidikan dan Kebudayaan daerah dan sebanyak 17,4\% atau 4 orang dari pengurus pokjar merupakan pensiunan pengawas SD hal ini mengindikasikan bahwa rata-rata pengurus pokjar merupakan pengawas SD yang bekerja di UPTD tingkat kecamatan. Selain itu terdapat $17,4 \%$ pengurus pokjar merupakan pensiunan pengawas SD dinas pendidikan dan kebudayaan baik ditingkat kecamatan maupun ditingkat kota/kabupaten. Selain itu 69,6\% atau 16 pengurus pokjar berjenis kelamin laki-laki dan 7 orang atau sebanyak $40,4 \%$ berjenis kelamin perempuan yang artinya pengurus pokjar didominasi oleh laki-laki dibandingkan pengurus pokjar yang perempuan. Dari 23 pengurus pokjar yang diwawancarai menyebutkan bahwa setiap pokjar memiliki tim dan struktur kepengurusan yang membantu pelayanan di sekretariat dan di sekolah di lokasi tutorial dan lokasi ujian, rata-rata tim tersebut terdiri dari ketua, sekretaris dan bendahara. Seperti pengurus pokjar Kabupaten Serang yang diketuai oleh sekretaris dinas pendidikan dan kebudayaan Kabupaten Serang yaitu Dedi Arief Rohidi, Irwan Nuryana sebagai bendahara, Erwin dan Yunus sebagai petugas di sekretariat Pokjar Serang.

\section{Peranan Pengurus Kelompok Belajar Program Pendidikan Dasar dalam penyelenggaraan Layanan Sistem Belajar Jarak Jauh UT Serang}

Mengamati karakteristik pengurus pokjar dan penjabaran tentang peranan pengurus pokjar diperoleh pengertian pengurus pokjar yaitu dua orang atau lebih yang berkoordinasi dengan UPBJJ memiliki struktur kepengurusan ditingkat kecamatan dan atau ditingkat kabupaten/kota untuk mengelola kelompok belajar mahasiswa pendas yang berdomisili di wilayah kecamatan dan kabupaten/kota di propinsi Banten. Memperhatikan Surat Pembantu Rektor III Universitas Terbuka Nomor 2292/UN31/LL/2013 tanggal 30 Januari 2013 yang menjelaskan bahwa pengurus pokjar di SK kan oleh Dinas yang ditembuskan kepada UPBJJ, kemudian menurut pedoman kerjasama UPBJJ mitra-pokjar dalam Form KS03-RK06b-RII.0 tanggal 25 Juni 2013 Universitas Terbuka yang menyatakan pengurus pokjar sebagai pihak kedua memiliki kewajiban kepada mahasiswa yaitu mengkoordinasi mahasiswa UT dalam hal memperoleh bahan ajar, layanan bantuan belajar, informasi tentang program-program pendidikan UT, informasi tentang cara registrasi (registrasi pertama, registrasi mata kuliah) termasuk registrasi online, penyelesaian kasus registrasi dan ujian, informasi tentang kegiatan-kegiatan kemahasiswaan (program kreativitas mahasiswa/pkm, beasiswa, disporseni, kegiatan paduan suara, kegiatan kerohanian, program mahasiswa wirausaha/pmw).

Pengurus pokjar program pendas memiliki peranan dalam penyelenggaraan layanan sistem belajar jarak jauh di UPBJJ-UT Serang yang siginifikan seperti dalam kegiatan:

a. Promosi UT

Sebanyak 19 pengurus pokjar melakukan promosi secara insedental dengan memanfaatkan acara-acara atau kegiatan yang melibatkan guru-guru SD seperti pertemuan PGRI, kepada mahasiswa pendas yang aktif di wilayah Pokjar. sedangkan 4 pokjar melakukan promosi secara terjadwal ke sekolah atau ke UPTD yang masih memiliki guru-guru SD yang belum SI atau belum linier SI PGSD. Media yang digunakan hanya leaflet dan spanduk. 
b. Registrasi pertama mahasiswa baru

Masa registrasi 2015.1, sebanyak 16 pengurus pokjar mampu merekrut mahasiswa mulai dari 26 orang sampai dengan 231 orang mahasiswa baru sedangkan pada registrasi 2015.2, 17 pengurus pokjar mampu merekrut mahasiswa baru mulai dari 38 orang sampai dengan 258 orang mahasiswa baru.

c. Registrasi matakuliah paket dan ujul

Dalam kegiatan registrasi, sebanyak 21 pengurus Pokjar melakukan pembayaran SPP secara kolektif ke Bank baik SPP untuk matakuliah paket semester, SPP untuk matakuliah Ujul, matakuliah ujian online dan matakuliah ATPEM.

d. Orientasi Studi Mahasiswa Baru (OSMB)

Pada masa registrasi 2015.1 seluruh pokjar melaksanakan OSMB di aula UPBJJ-UT Serang sedangkan pada masa registrasi 2015.2 kecuali pokjar Kabupaten Tangerang, Kota Tangerang dan Karang Tengah, melaksanakan OSMB dipokjar masing-masing.

e. Distribusi Bahan Ajar

Pada masa registrasi 2015.1 dan masa registrasi 2015.2 diketahui 22 pengurus pokjar mengambil bahan ajar ke UPBJJ. Di sekretariat pokjar modul disusun berdasarkan semester, diikat tali rapi dan disusun kembali kedalam kardus dan dibagikan dua minggu sebelum tutorial dilaksanakan.

f. Tutorial Praktek PKP dan PKM

Pada masa tutorial 2015.1 hanya pengurus pokjar Cilegon dan Cipanas yang tidak melakukan tutorial praktek PKP maupun PKM karena mahasiswa pendas Cilegon dan Cipanas tidak ada yang registrasi matakuliah PKP dan PKM. Sedangkan untuk masa tutorial 2015.2 pokjar Cibadak dan pokjar Saketi yang tidak melaksanakan tutorial praktek PKP maupun PKM.

g. Tutorial Wajib

Selama delapan kali pertemuan/tutorial pengurus pokjar berada di sekretariat sekolah dari pukul 07.30 WIB sampai dengan pukul 16.00 WIB melayani setiap mahasiswa yang membutuhkan pelayanan konsultasi, tutorial dan pelayanan administrasi seperti pemesanan untuk cetak LKAM, cetak surat keterangan kuliah, cetak daftar nilai ujian (DNU), cetak SK yudisium, daftar UPI, dan kasus nilai.

h. Ujian Pendas

Dalam kegiatan ujian pengurus pokjar berkoordinasi dengan penanggungjawab ujian, koordinator unit registrasi dan ujian UPBJJ-UT Serang dan dengan penanggungjawab tempat ujian (PJTU) untuk proses peminjaman tempat/sekolah tempat ujian, pengumpulan daftar nama pengawas ruang, pemesanan hotel dan konsumsi, penempelan nomor kursi, nomor ruang dan denah lokasi ujian.

i. Upacara Penyerahan ljasah (UPI)

Pengurus pokjar mendaftarkan alumni untuk menjadi peserta UPI, mengambil toga, menyiapkan akomodasi dari pokjar ke Pondok Cabe seperti yang dilakukan oleh pengurus pokjar Cilegon, pokjar Cibaliung, pokjar Pandeglang, pokjar Rajeg dan pengurus pokjar Tiga Raksa.

Untuk melaksanakan peranan tersebut pengurus pokjar melakukan koordinasi dengan UPBJJ baik untuk perekrutan mahasiswa baru dan tutorial yang dilakukan selama delapan kali pertemuan seperti yang disampaikan oleh Nugraheni (2009:2) bahwa dalam sistem PTJJ tidak semua kegiatan belajar dilakukan melalui media. Beberapa kegiatan seperti tutorial dan praktikum dilaksanakan secara tatap muka sebagaimana pada sistem pendidikan konvensional. Kegiatan 
tersebut tentu saja membutuhkan pengelolaan yang dilakukan baik orang maupun organisasi seperti pengurus pokjar maupun UPBJJ-UT Serang sesuai pendapat Keegan (1983, dalam Rusyana, 2012:1-2) karakteristik PJJ salah satunya adalah adanya suatu institusi yang mengelola program pendidikan, inilah yang membedakan dengan kegiatan seseorang yang belajar sendiri dirumah atau studi pribadi.

Keberadaan 23 pengurus kelompok belajar pendas di UPBJJ-UT Serang juga sesuai dengan Rusyana (2012:3) yang menuliskan bahwa banyak lembaga-lembaga tutorial yang menjamur menggunakan nama UT dalam kegiatan operasionalnya. Kegiatan operasional tersebut dalam rangka pengelolaan belajar jarak jauh terutama untuk mahasiswa pendas yang ada diseluruh kecamatan di wilayah Banten dan tentunya kegiatan operasional tersebut tidak lepas perencanaan dan penganggaran baik untuk pembelian alat tulis kantor, sewa sekretariat, transport tutor, dan untuk honor pengurus pokjar yang sebagian besar pengurus pokjar berpendapat honor adalah salah satu hak sebagai pengurus pokjar sebagai imbalan jasa pengelolaan belajar jarak jauh.

Pengurus pokjar melakukan pungutan uang partisipasi sebagai dana untuk anggaran operasional pokjar yang besarnya bervariasi antara satu pokjar dan pokjar lainnya di UPBJJ-UT Serang. Besarnya uang partisipasi mahasiswa antara Rp 250.000 sampai dengan Rp.500.000/semester/mahasiswa sedangkan untuk tutorial praktek PKM uang partisipasi mahasiswa yang ditetapkan oleh pengurus pokjar antara Rp 150.000 sampai dengan Rp 1000.000/mahasiswa dan untuk tutorial praktek PKP uang partisipasi mahasiswa yang ditetapkan pengurus pokjar antara Rp 400.000 sampai dengan Rp 1.200.000/mahasiswa kecuali pokjar Kabupaten Tangerang dan Kota Tangerang yang tidak menarik uang partisipasi untuk tutorial praktik PKP dan PKM mahasiswa.

Kisaran penarikan uang partisipasi mahasiswa disampaikan oleh pengurus pokjar Malingping yang menjelaskan bahwa sebagian besar mahasiswa pendas pokjar Malingping adalah guru honorer di SD terpencil yang gajinya tidak memadai untuk kesejahteraan hidup apalagi untuk biaya sekolah UT, oleh karena itu pengurus menetapkan uang partisipasi sebesar Rp 250.000/mahasiswa/semester selain untuk biaya diatas digunakan juga untuk akomodasi perjalanan dari Malingping (sekretariat pokjar) ke Kota Serang (UPBJJ) yang jarak tempuhnya mencapai $130 \mathrm{KM}$.

Penarikan uang partisipasi untuk tutorial praktek PKP dan PKM ini menurut pengurus pokjar TN (2015) yang diwawancari oleh peneliti mengatakan bahwa tutorial praktik PKP dan PKM dilakukan tidak bersamaan dengan tutorial wajib yang menyebabkan pengurus pokjar harus membayar transport supervisor 1 yang besarnya antara Rp 100.000/supervisor I sampai dengan Rp 400.000/supervisor I selama 8 kali bimbingan PKP/PKM, untuk membeli ATK, untuk membeli konsumsi selama bimbingan dan untuk membayar kebersihan dan keamanan sekolah yang digunakan untuk praktek PKP dan PKM. Penetapan jumlah uang partisipasi ini tentu saja dilakukan secara sepihak oleh pengurus pokjar kepada mahasiswa yang masih membutuhkan layanan dari pengurus pokjar. Dengan kondisi mahasiswa pendas yang masih bergantung kepada pengurus pokjar apalagi di lapangan seperti yang peneliti amati hampir sama dengan fenomena yang disampaikan oleh Nugraha (1992 dalam Rusyana, 2012:5) bahwa mahasiswa Pendas yang hadir tutorial masih ingin disuapi karena kemampuan yang beragam, tidak siap, minat dan kemampuan membaca kurang.

Hal tersebut membuktikan bahwa tutorial masih sangat dibutuhkan dalam belajar jarak jauh mahasiswa pendas dan untuk mengelola tutorial dibutuhkan pengurus, tutor dan fasilitas serta biaya untuk mendukung terlaksananya tutorial selain SPP wajib yang dibayarkan ke UT mahasiswa juga harus membayar uang partisipasi kepada pengurus pokjar untuk mendapatkan layanan belajar jarak jauh seperti tutorial. Kenyataan ini juga pernah disampaikan oleh Rusyana (2012:3) bahwa biaya 
perkuliahan yang ditetapkan oleh lembaga-lembaga tutorial mitra jauh dari ketetapan Universitas Terbuka.

Pengurus pokjar tetap menjalankan kewajiban terhadap mahasiswa pendas maupun terhadap UPBJJ, meskipun pengurus pokjar pendas UPBJJ-UT Serang tidak memiliki perjanjian kerjasama tertulis dengan UPBJJ. Hubungan organisasional antara UPBJJ dengan pokjar hanya bersifat koordinasi pengelolaan mahasiswa. Hal ini berarti pengurus pokjar bukan perpanjangan tangan dari UPBJJ karena dalam hubungan kedinasan antara UPBJJ dengan pengurus pokjar tidak didasari oleh perjanjian kerjasama yang menuangkan tentang Job descriprtion, tentang kewajiban, kewenangan dan hak yang harus dipertanggungjawabkan kepada UT seperti tertuang dalam pedoman kerjasama UPBJJ mitra-pokjar dalan Nomor Form ISO:KS03-RK06b-RII.0 tanggal 25 Juni 2013 Universitas Terbuka. Akibat hubungan organisasi koordinasi tanpa perjanjian tertulis, Toha $d k k$ (2010:37) menjelaskan bahwa apabila di dalam uraian tugas tidak cukup dijelaskan tentang peran masing-masing anggota organisasi, maka akan timbul kemenduaan peran sehingga orang tidak merasa yakin dalam berinteraksi satu sama lain dan konflik kemenduaan peran tersebut mengakibatkan penurunan kepuasan kerja dan berkurangnya keikatan/komitmen para anggota terhadap organisasinya. Hal ini terlihat pada komitmen yang berbeda antara UPBJJ UT dengan komitmen pengurus pokjar dalam melayani mahasiswa pendas yang menuntut setiap layanan yang diberikan pengurus pokjar berhak mendapatkan imbalan atas jasa yang diberikan kepada mahasiswa dan UPBJJ juga tidak memiliki kewenangan untuk melakukan teguran langsung atas ketidaksesuaian peranan yang dilakukan oleh pengurus pokjar. Berbeda dengan pendapat dari peneliti terdahulu menurut Shanti Devi dan Raja Usman (2010:99), yang menjelaskan bahwa pengurus pokjar adalah perpanjangan tangan yang dimilik oleh UT di daerah-daerah kabupaten/kota bahkan sampai ke tingkat kecamatan yang berfungsi menjalankan operasional harian kepada mahasiswa/masyarakat.

Kesimpulanya adalah merujuk pada pengertian peranan (role) menurut Soekanto (2009), peranan merupakan proses dinamis kedudukan (status). Apabila seseorang melaksanakan hak dan kewajibannya sesuai dengan kedudukannya, dia menjalankan suatu peranan (Soekanto, 2009:212213). Dalam hal ini berarti pengurus pokjar yang telah melaksanakan kewajibannya dan mendapatkan haknya dari UPBJJ dan mahasiswa memiliki peranan dalam penyelenggaraan sistem layanan belajar jarak jauh bagi mahasiswa pendas di UPBJJ-UT Serang.

\section{PENUTUP}

Pengurus pokjar program pendas memiliki peranan dalam penyelenggaraan layanan sistem belajar jarak jauh di UPBJJ-UT Serang yang siginifikan seperti alam kegiatan: kegiatan promosi Universitas Terbuka, kegiatan registrasi pertama mahasiswa baru, kegiatan registrasi matakuliah paket dan ujul, kegiatan Orientasi Studi Mahasiswa Baru (OSMB), kegiatan Tutorial Praktik PKP dan PKM, kegiatan tutorial wajib, kegiatan ujian pendas dan Suo, kegiatan Upacara Penyerahan ljasah (UPI).

Pembahasan pada artikel ini juga memperkuat hubungan kedinasan antara UPBJJ dengan pengurus pokjar tidak didasari oleh perjanjian kerjasama yang menuangkan tentang Job descriprtion, tentang kewajiban, kewenangan dan hak yang harus dipertanggungjawabkan kepada UT hal ini menyebabkan adanya komitmen yang berbeda antara UPBJJ UT dengan komitmen pengurus pokjar dalam melayani mahasiswa pendas. Pengurus pokjar berharap setiap layanan yang diberikan berhak mendapatkan imbalan atas jasa yang diberikan kepada mahasiswa sedangkan UPBJJ tidak memiliki kewenangan untuk melakukan teguran langsung atas ketidaksesuaian peranan yang dilakukan oleh pengurus pokjar tersebut. 


\section{REFERENSI}

Devi, Shanti \& Raja Usman. (2010). Peranan Pengurus Pokjar UPBJJ-UT Pekan Baru dalam mempromosikan Universitas Terbuka. Jurnal Pendidikan Terbuka dan Jarak Jauh, Vol. 11, No. 2, September 2010, 99-107.

Darmanto, Muharto Toha. (2010). Perilaku Organisasi. Jakarta. Universitas Terbuka.

Katalog UT Pendas. (2015). Tangerang,Universitas Terbuka.

Nugraheni, Endang (2009). Peranan Pendidikan Terbuka Dan Jarak Jauh Dalam Meningkatkan Daya Jangkau Pendidikan Tinggi Di Asia Tenggara. Jurnal Pendidikan Terbuka dan Jarak Jauh, Vol. 10, No. 1, Maret 2009, 1-9.

Rusyana, Enang. (2012). Penerapan Tutorial Antarteman dalam Tutorial Bahasa Indonesia oleh Tutor DII PGSD. http://digilib.upi.edu/digitalview.php? Digital_id=87. Di akses 11 November 2015.

Soerjono Soekanto. (2009). Sosiologi Suatu Pengantar, Edisi Baru, Jakarta, Rajawali Pers.

\section{Dokumen Peraturan}

Surat Pembantu Rektor III Nomor 2292/UN31/LL/2013

Internet

http://id.wikipedia.org/wiki/Kelompok_belajar, diunduh pada tanggal 10 Februari 2015 pukul 10.00 Wib.

http://roniir.blogspot.com/2012/03/belajar-kelompok.html diunduh pada tanggal 10 Februari 2015 pukul 10.15 Wib.

http://www.ut.ac.id/berita/internasional/108-informasi-umum-ut/informasi-mahasiswa-ut/323-tentangptji.html diunduh pada tanggal 10 Februari 2015 pukul 11.15 Wib.

www.denpasar.ut.ac.id, diunduh pada tanggal 10 Februari 2015 pukul 11.15 Wib. www.surabaya.ut.ac.id, diunduh 31 Juli 2015 pukul 15.00 Wib. 